\title{
PALEOEPIDEMIOLOGY OF INTESTINAL PARASITES AND LICE IN PRE-COLUMBIAN SOUTH AMERICA*
}

\author{
PALEOEPIDEMIOLOGÍA DE PARÁSITOS INTESTINALES Y PIOJOS \\ EN SUDAMÉRICA PRECOLOMBINA
}

\author{
Adauto Araújo ${ }^{1}$, Karl Reinhard ${ }^{2}$, Daniela Leles ${ }^{1}$, Luciana Sianto ${ }^{1}$, Alena Iñiguez, \\ Martin Fugassa ${ }^{4}$, Bernardo Arriaza ${ }^{5,6,7}$, Nancy Orellana $^{6,8,9}$, and Luiz Fernando Ferreira ${ }^{1}$
}

\begin{abstract}
Some human parasites originated in prehominid ancestors in Africa. Nematode species, such as Enterobius vermicularis (pinworm), hookworms and Trichuris trichiura are shared by humans and other close phylogenetic primates (Pan and Gorilla), showing that they infected a common ancestor to this group. When humans migrated from Africa to other continents they carried these parasites wherever climate conditions allowed parasite transmission from host to host. Other parasites, however, were acquired throughout human biological and social evolutive history when new territories were occupied. Paleoparasitology data is a valuable source to recover emergence and disappearance of parasite infections through analysis of archaeological remains. Parasites can be used as biological markers of prehistoric human migrations. They are also indicators of diet, as parasite life cycles are related to specific kinds of food consumed by human groups in the different habitats they occupied. We review paleoparasitological findings in South America, comparing human-host and intestinal parasites with life conditions and environmental relationships through time.
\end{abstract}

Key words: Paleoparasitology, coprolites, mummies, infectious diseases, ancient diseases, parasite-human evolution.

\begin{abstract}
Algunos parásitos humanos se originaron en ancestrales prehomínidos de Africa. Especies de nemátodos tales como Enterobius vermicularis $y$ Trichuris trichiura son compartidos por los humanos y otros primates filogenéticamente emparentados (Pan and Gorilla), lo cual indica que tales parásitos antiguamente infectaron a un ancestro común de estos grupos. Cuando los humanos migraron desde Africa a otros continentes, llevaron consigo parásitos a lugares donde las condiciones climáticas permitieran su transmisión de huésped a huésped. Sin embargo, otros parásitos fueron adquiridos a través de la historia evolutiva humana biológica y social, durante la ocupación de nuevos territorios. Las evidencias paleoparasitológicas, encontradas a través del análisis de material arqueológico, son una fuente valiosa para recuperar información de infecciones parasitarias emergentes y desaparecidas. Los parásitos pueden ser usados como marcadores biológicos de migraciones humanas prehistóricas. Además de esto, son indicadores de dieta, debido a que los ciclos de vida parasitarios están relacionados con ciertos alimentos que fueron consumidos por grupos humanos en los diferentes hábitats ocupados. El objetivo de esta revisión bibliográfica es reunir los hallazgos paleoparasitológicos en Sudamérica y comparar la relación huésped humano y parásitos intestinales con condiciones de vida y relaciones ambientales a través del tiempo.
\end{abstract}

Palabras claves: paleoparasitología, coprolitos, momias, enfermedades infecciosas, enfermedades antiguas, evolución parásito-humano.

Parasites have been found in ancient remains throughout the world (Bouchet et al. 2003; Gonçalves et al. 2003). Coprolites and latrine contents are the main source of intestinal parasite eggs. Protozoan cysts, however, are not as easy to identify. Nevertheless, serologic techniques have been successfully applied to identify Giardia duodenalis, Giardia intestinalis and Entamoeba histolytica

* Este artículo fue presentado en el Taller de Bioarqueología "Avances y Desafíos del Paleoambiente y la Paleoparasitología", Arica, noviembre 2008. De 15 ponencias expuestas 7 fueron seleccionadas para ser evaluadas por investigadores externos. Luego fueron editadas por Bernardo Arriaza y Nancy Orellana, en su calidad de editores invitados en este número.

1 Escola Nacional de Saúde Pública, Fundação Oswaldo Cruz, Rua Leopoldo Bulhoes 1480, CEP 21041-210, Rio de Janeiro, Brasil.adauto@ensp.fiocruz.br; dleles03@yahoo.com; lucianasianto@gmail.com

2 University of Nebraska, Lincoln, Nebraska, Estados Unidos. kreinhard1 @ unl.edu

3 Instituto Oswaldo Cruz, Fundação Oswaldo Cruz, Av. Brasil 4365, CEP 21045-900, Rio de Janeiro, Brasil. alena @ ioc.fiocruz.br CONICET-Universidad Nacional de Mar del Plata, Argentina. mhfugassa@ hotmail.com

5 Instituto de Alta Investigación, Universidad de Tarapacá, Arica, Chile. barriazaarica@gmail.com

Convenio de Desempeño-UTA/Mineduc, Universidad de Tarapacá, Arica, Chile.

7 Departamento de Antropología, Universidad de Tarapacá, Arica, Chile.

8 Universidad de la Cordillera, La Paz, Bolivia. nancy.orellana@ gmail.com

9 Museo Nacional de Etnografía y Folklore, La Paz, Bolivia. 
antigens in human coprolites (Gonçalves et al. 2002, 2004; Le Bailly et al. 2008). Other parasites, such as the protozoan Trypanosoma cruzi was recovered from mummified tissues and bone fragments by molecular biology techniques (Aufderheide et al. 2004; Fernandes et al. 2008; Ferreira et al. 2000; Guhl et al. 1999, 2000; Lima et al. 2008).

Parasitology is relevant to anthropology and the impact of parasites on human culture can be seen in language, art, religion, biology and archaeology (Araújo et al. 2003). Parasites and parasitic disease have cultural expressions as represented in Moche ceramic art (Heck 2004). The use of regular parasitological techniques, modified and adapted to paleoparasitological research increased and expanded parasite findings to other kinds of archaeological remains (Fugassa et al. 2006; Fugassa, Sardella et al. 2008; Harter et al. 2003; Harter-Lailheugue and Bouchet 2006).

\section{History of Paleoparasites Found on Archaeological Remains}

Since the first studies in South American human coprolites (Pizzi and Schenone 1954), paleoparasitology has developed as a new research line and this new science appeared based on solid data founded on parasite findings from well-dated and well-identified context, as predicted by Cockburn (1967). Common wisdom about human health conditions and parasite infections in the New World was challenged by paleoparasitological finds. Hookworm (ancylostomids), whipworm (Trichuris trichiura), pinworm (Enterobius vermicularis), and roundworm (Ascaris lumbricoides) were found infecting prehistoric populations both in North and South America.

Paleoparasitology focuses on the recovery of parasites from archaeological sites to further elucidate the ancient impacts of parasites on culture. Tracing the origins of parasites is one research thread of importance to paleopathology (Reinhard 1990). Parasitism has a central role in bioarchaeology (Reinhard 2008; Reinhard and Bryant 2008) and has long been recognized as a tool for the archaeologist (Reinhard 1992).

As reviewed by Reinhard and Bryant (2008), the relation between cultural development and the nature of parasitism has long been investigated. Reinhard (1988) first formalized this area of research in the Southwestern United States by testing Cockburn's
(1971) hypotheses about the impact of agriculture on parasitism. Reinhard showed that zoonotic infections, long standing in ancient populations, nearly disappeared in horticulturalists as humanspecific parasites emerged. Martinson et al. (2003), Reinhard and Buikstra (2003) and Santoro et al. (2003) continued to explore the impact of parasitic disease ecology in the Andes. They clearly defined the role of trade, dress, and water contamination on parasitic disease among the Chiribaya of Peru (Martinson et al. 2003; Reinhard and Buikstra 2003). Santoro et al. (2003) demonstrated that empire development dramatically modified parasite ecology of the Lluta Valley, Chile, during Inka expansion to this lowland territory.

Reinhard (1992) noted that the most sensational contribution of paleoparasitology was towards a better understanding of the first human migrations to the New World. In addition, Araújo et al. (1981), Araújo, Reinhard et al. (2008), and Montenegro et al. (2006) stated that human coastal and transoceanic migrations also need consideration because helminth could not survive the colder Beringia climate. Further work by Reinhard and Bryant (2008) introduced the concept of pathoecology, which links parasitism to diet, environmental stress, and other culturally-defined behaviors in the definition of ancient disease.

Molecular biology techniques were also applied in diagnosing intestinal parasites. Loreille et al. (2001) and Loreille and Bouchet (2003) discussed the origin and evolution of Ascaris lumbricoides and Ascaris suum parasitism based on DNA studies performed on parasite eggs recovered from mediaeval latrines in Europe. Recently, Leles et al. (2008) applied molecular biology techniques and were able to recover ancient Ascaris lumbricoides DNA sequences from South American samples, negative by microscopy. These findings illustrate the importance of molecular biology techniques in diagnosing parasites in ancient remains. Molecular biology techniques allow the study of genetic evolution of parasites and the timing of their introduction into human populations (Dittmar et al. 2006; Dittmar 2009). By recovering aDNA (ancient DNA) sequences and genotyping parasites from human remains increases the possibility to reconstruct the early dispersion patterns of parasites (Raoult and Drancourt 2008).

This paper summarizes the extent of the knowledge of intestinal parasite remains from South 
America. As such, it familiarizes the reader with the current findings of parasites from this ecologically diverse and culturally complex area. We review intestinal parasite infections in pre-Columbian South America. Paleoparasitological data is used by archaeologists and anthropologists to reconstruct ancient events based on parasite life cycles and biological requirements to maintain transmission from host to host. Climate changes are also associated with the presence of parasite infections in ancient people. For this purpose, paleoparasitological data gathered by the laboratories of Fundação Oswaldo Cruz, Universidad Nacional de Mar del Plata, and Universidad de Tarapacá-Arica, as well as data from other sources published in the literature were reviewed. The goal of this paper is to discuss paleoparasitology results in South America aiming to improve techniques and integrate data obtained by the laboratories involved in this matter.

\section{Techniques Used to Analyse Bioarchaeological Material}

Organic remains were examined by parasitological regular techniques after rehydration using a trisodium phosphate aqueous solution $\left(\mathrm{Na}_{3} \mathrm{PO}_{4}{ }^{-}\right.$ $0.5 \%)$. According to the nature of the sample, different techniques are recommended. For most coprolite analyses, spontaneous sedimentation in glass jars is recommended (Araújo et al. 1998; Lutz 1919). To prevent bacterial and fungal growth or taphonomic processes that may cause DNA degradation, thus interfering in molecular biology technique that may be applied, all the remaining sediment in the jars should be preserved refrigerated (Pruvost et al. 2007).

In some archaeological contexts, coprolites are the main source for paleoparasitology analysis. For example, in northeasthern Brazil coprolites are found dispersed in archaeological layers under rock-shelters or inside caves (Bouchet et al. 2003). Mummified bodies are rarely found in Brazilian archaeological sites. According to Mendonça de Souza (pers. comm. 2008) preservation of the dead was never a common practice among Brazilian indigenous cultures because they believe the soul should be released soon after death. Just after death the individual was cremated, buried, or sometimes the ashes were eaten by others (Chagnon 1983). Paleoparasitological research in Brazil started with an interest in knowing what parasite infections existed before the coming of Europeans and Africans to the Americas (Ferreira et al. 1988). These results were used to trace prehistoric migration routes for the peopling of the continent (Araújo et al. 1981; Araújo, Reinhard et al. 2008; Araújo, Reinhard and Ferreira 2008; Reinhard et al. 2001). Wild animal coprolites were also examined from many archaeological sites, especially focused on parasites of animals that may infect humans (Chame 2003; Sianto et al. 2005). Due to the collaboration with the University of Nebraska, Lincoln, ancient food remains turned to be also a research line at Fundação Oswaldo Cruz (FIOCRUZ). Molecular paleoparasitology has a special laboratory to develop techniques and diagnoses in conditions avoiding modern DNA contamination. The Laboratory of Paleoparasitology at FIOCRUZ, also has an image bank that will soon be available on the Internet.

A considerable amount of American paleoparasitological data appeared recently in the literature. Even Southern Patagonian coprolites were collected and examined (Fugassa 2007, 2008; Fugassa, Bayer and Sardella 2008). However as climatic conditions in Patagonia are not conducive to preservation, organic materials are continuously exposed to extreme dryness and cold and sometimes to water percolation. Due to the scarcity of coprolites and other organic material a microscopic method was developed to search for parasites at the Laboratory of Paleoparasitology of the University Nacional de Mar del Plata, Argentina (Fugassa et al. 2006). The method used sediments recovered from the pelvic girdle and proved to be effective; it allowed for recovery of parasite eggs from human sacral foramina stored in museum and scientific institutions (Jones 1982; Fugassa, Denegri et al. 2006; Reinhard 1992). The main reason for pursuing paleoparasitological research in Argentina is to understand the impact of disease during the paleoepidemiological transition caused by the contact of Europeans with Patagonian Aborigins.

At the Universidad Nacional Mayor de San Marcos in Lima, Perú, Inés Gárate and her team applied regular parasitological techniques to examine human coprolites excavated in the archaeological site of Caral to search for parasites (Gárate et al. 2005). Caral is the oldest city of the western hemisphere, dated of 5000 years before present (BP) (Solis et al. 2001). Paleoparasitological research started recently exploring this archaeological site material, and first results are expected to be published soon. Paleoparasitology in Peruvian archaeological remains 
has a tradition in coprolite (Patrucco et al. 1983) and mummy analysis (Fornaciari et al. 1992; Salo et al. 1994), but also on ectoparasites (Rick et al. 2002; Dittmar 2000; Dittmar et al. 2003; Raoult et al. 2008). Another group interested in paleoparasitological research was recently created by Luis Huamán and Hugo Flores, and their students at the Universidad Cayetano Heredia. The main interest of these specialists is plant and food remains and parasite associated with food resources and diet.

Regarding the study of parasites in mummified bodies, the Chinchorro mummies of Northern Chile present an interesting challenge. The most ancient mummies were prepared by defleshing the body to the bones and taking out abdominal viscera so intestinal contents are not expected to be found. Desert climate is especially suitable to preserve coprolites and paleoparasites. Fouant et al. (1982) reported a low incidence of parasites in Chilean and Peruvian mummies. Considering the tradition of paleoparasitological research in Chile, the interests varied from tuberculosis and Chagas disease (Rothhammer et al. 1985), intestinal parasites, and diet as well as implications of ENSO phenomenon (Arriaza et al. 2010; Williams et al. 2008).

In all the laboratories involved in paleoparasitologial research, ectoparasites have been studied. Mummies of humans and other animals have been searched for lice, fleas, and other arthropods. It is important to look for parasites in the wrapping tissues of the mummies and collect sediment samples near the body.

\section{Intestinal Parasites}

Paleoparasitological research proved that common intestinal parasites infected pre-Columbian people long before European and African migrations (Gonçalves et al. 2003). Data also showed that Amerindians acquired infections by eating intermediate hosts or being in close contact with vectors and hosts of parasites that infect humans (Patrucco et al. 1983; Sianto et al. 2005).

Some intestinal parasites that originated in hominid African ancestors were introduced into South America with their human hosts long before European conquest (Araújo, Reinhard, Ferreira et al. 2008). Prehistoric people who lived on the American continent were infected with common bacteria, protozoa, and helminths as in other parts of the world. Although hookworms, pinworm, whipworm, and roundworm infection were the same, prevalence rates among pre-Columbian populations and transmission dynamics should behave in a different way according to the different cultures where they were infecting. Parasite transmission dynamics was not the same in the city of Caral, in Peru, or in the Atacama Desert where the Chinchorros lived, and in the semi-arid region of Brazilian northeast where hunter-gathering strategy was used by pre-historic groups. Thus, generalization on parasites and ecology may lead to erroneous interpretations (Figure 1 and Table 1). Brazilian groups were numerous and lived in crowded villages before the European continent conquest (Heckenberger et al. 2008). Contrary to what is the common knowledge, Amerindian groups living in the Brazilian coast where numerous and just before European conquest some groups were displaced to the interior after tribal wars, and in turn exterminated small groups of hunter-gatherers living in caves and rock-shelters (Medeiros 2002).

Studies about the impact of European contact with indigenous population opened a new line of research, especially regarding paleoepidemiological transition unleashed by European arrival (Guichón et al. 2006). Fugassa, Cicchino et al. (2008) showed that hunter-gatherer groups of Patagonia would have had a parasitological profile, zoonosis caused by close wild animals contact or ingestion of intermediate hosts meat and vegetables contaminated with parasite eggs or cysts, as well as arthropods, such as oribatids, which are intermediate hosts for anoplocephalids. After European contact parasite infections and relative abundance of the common human intestinal worms Ascaris lumbricoides and Trichuris trichiura changed significantly (Fugassa et al. 2006). Crowding indigenous populations in religious missions, reducing mobility of the nomadic groups, and the fast and abundant arrival of domestic animals, mainly sheeps, caused a rapid change of the helminth and protozoan fauna, due to human/animal parasite cross infections. European also caused a reduction of local fauna. Europeans also introduced food storage, attracting rodents and their parasites to dwellings (Guichón et al. 2006).

Trichuris trichiura (whipworm) infection was common in South America on both sides of the Andean cordillera (Gonçalves et al. 2003). Whipworm eggs were the first to be found in a South American mummy, together with Entamoeba coli cysts (Pizzi and Schenone 1954). Enterobius 


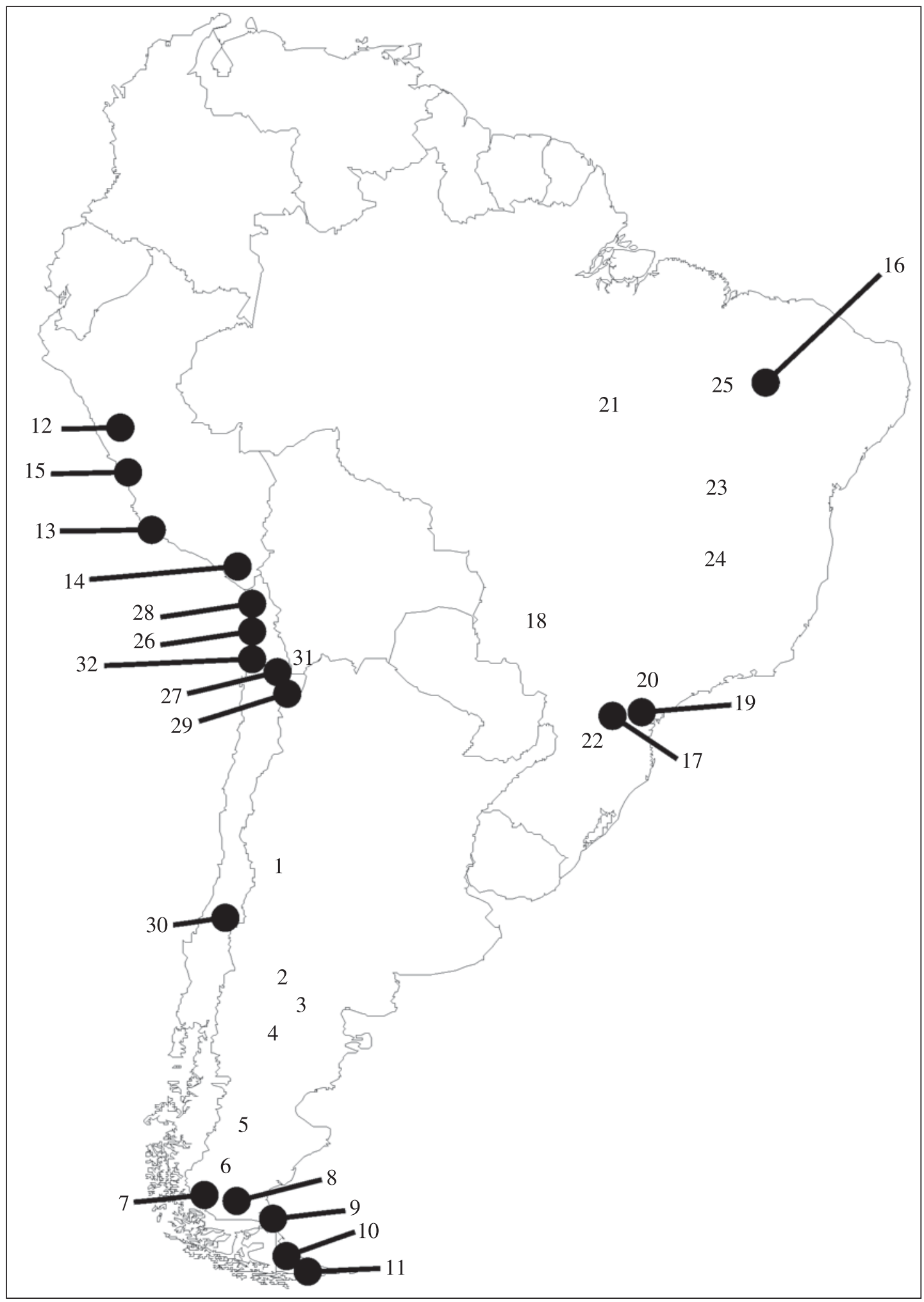

Figure 1. Map of South America showing the location of paleoparasitological findings listed in Table 1. Mapa de Sudamérica, muestra la localización de los paleoparásitos hallados, citados en la Tabla 1. 
Table 1. Summary of South American paleoparasitological findings. Resumen de los hallazgos paleoparasitológicos en Sudamérica.

\begin{tabular}{|c|c|c|c|c|c|}
\hline \multirow{2}{*}{ Country } & \multicolumn{5}{|c|}{ South America } \\
\hline & Archaeological Site & No & Date & Parasites & Reference \\
\hline \multirow{11}{*}{ Argentina } & Pie de Palo & 1 & not available & Enterobius vermicularis & Fugassa et al. 2006 \\
\hline & Perito Moreno, Santa Cruz & 2 & $6,540 \pm 110 \mathrm{BP}$ & $\begin{array}{l}\text { Enterobius vermicularis } \\
\text { Rabditoid larvae } \\
\text { Trichuris sp. }\end{array}$ & Fugassa 2008 \\
\hline & Nombre de Jesús, Cabo Virgenes & 3 & not available & Ascaris lumbricoides & Fugassa et al. 2006 \\
\hline & Orejas de Burro, Santa Cruz & 4 & $3,720-3,978 \mathrm{BP}$ & Ascaridid & Fugassa 2006 \\
\hline & Valle Encantado, Neuquén & 5 & $1,000-500 \mathrm{BP}$ & Ancylostomid & Gonçalves et al. 2003 \\
\hline & Las Mandibulas, Tierra del Fuego & 6 & Historic & Capillarids & Fugassa et al. 2008 \\
\hline & Caleta Falsa, Tierra del Fuego & 7 & 850 years BP & Capillarids & Fugassa et al. 2008 \\
\hline & Cerro Norte XI, Pali Aike, Santa Cruz & 8 & not available & Capillarids & new findings \\
\hline & Salitroso, Santa Cruz & 9 & not available & Trichuris trichiura & new findings \\
\hline & Parador Nativo, Rio Negro & 10 & $1,513 \pm 48 \mathrm{BP}$ & Trichuris trichiura & Fugassa et al. 2006 \\
\hline & Centro Minero, Rio Negro & 11 & $689 \pm 44 \mathrm{BP}$ & Trichuris trichiura & Fugassa et al. 2006 \\
\hline \multirow{4}{*}{ Peru } & Huamey Valley & 12 & $1,000 \mathrm{AD}$ & Trichuris trichiura & Patrucco et al. 1983 \\
\hline & Coast (southern) & 13 & $10,000-4,000 \mathrm{BP}$ & D. pacificum & Patrucco et al. 1983 \\
\hline & Osmore, Peru & 14 & $1,020-1,476 \mathrm{BP}$ & D. pacificum & Patrucco et al. 1983 \\
\hline & Huaca Prieta & 15 & $3,000 \mathrm{BP}$ & Diphyllobotrium sp. & Callen and Cameron 1960 \\
\hline \multirow{10}{*}{ Brazil } & Toca do Meio, Piauí & 16 & $8,800 \pm 60 \mathrm{BP}$ & Ascaris lumbricoides & Leles et al. 2008 \\
\hline & Lapa Pequena, Minas Gerais & 17 & $8,000-7,000 \mathrm{BP}$ & Ascaris lumbricoides & Gonçalves et al. 2003 \\
\hline & Santa Elina, Mato Grosso & 18 & $4,000-2,000 \mathrm{BP}$ & $\begin{array}{l}\text { Ascaris lumbricoides } \\
\text { Hymenolepis nana }\end{array}$ & Gonçalves et al. 2003 \\
\hline & Gruta do Gentio II, Minas Gerais & 19 & $3,490 \pm 120-4,30 \pm 70 \mathrm{BP}$ & Ascaris lumbricoides & Leles et al. 2008 \\
\hline & Gentio Cave, Minas Gerais & 20 & $3,490 \pm 120-430 \pm 70 \mathrm{BP}$ & $\begin{array}{l}\text { Ascaris lumbricoides } \\
\text { Acantocephala }\end{array}$ & Gonçalves et al. 2003 \\
\hline & Pedra Furada, Piauí 1 & 21 & not available & Trichuris trichiura & Gonçalves et al. 2003 \\
\hline & Boqueirão Soberbo, Minas Gerais & 22 & $4,905 \pm 85-1,325 \pm 60 \mathrm{BP}$ & $\begin{array}{l}\text { Trichuris trichiura } \\
\text { Acantocephala }\end{array}$ & Ferreira et al. 1984 \\
\hline & Estrago Cave, Pernambuco & 23 & $2,000 \mathrm{BP}$ & Trichuris trichiura & Gonçalves et al. 2003 \\
\hline & Itacambira, Minas Gerais & 24 & not available & Trichuris trichiura & Confalonieri 1988 \\
\hline & Sítio do Meio, Piauí & 25 & not available & Ancylostomid & Gonçalves et al. 2003 \\
\hline \multirow{7}{*}{ Chile } & Tiliviche, Iquique & 26 & $4,110-1,950 \mathrm{BC}$ & $\begin{array}{l}\text { D. pacificum } \\
\text { Enterobius vermicularis } \\
\text { Ancylostomid }\end{array}$ & $\begin{array}{l}\text { Ferreira et al. } 1984 \\
\text { Gonçalves et al. } 2003\end{array}$ \\
\hline & Tulán, San Pedro de Atacama & 27 & $1,000 \mathrm{BC}$ & Trichuris trichiura & Ferreira et al. 1984 \\
\hline & Lluta Valley, Arica & 28 & $\begin{array}{l}\text { 1,200-1,500 AD } \\
\text { (Inka period) }\end{array}$ & $\begin{array}{l}\text { Trichuris trichiura } \\
\text { Hymenolepis nana }\end{array}$ & Santoro et al. 2003 \\
\hline & Toconao, San Pedro de Atacama & 29 & $2,500-2,100 \mathrm{BP}$ & Ancylostomid & Gonçalves et al. 2003 \\
\hline & El Plomo, Santiago & 30 & Pre-Columbian & Trichuris trichiura & Ferreira et al. 1984 \\
\hline & Catarpe, San Pedro de Atacama & 31 & $1,450-1,525 \mathrm{AD}$ & Trichonstrongylus sp. & Gonçalves et al. 2003 \\
\hline & San Miguel de Azapa & 32 & $4,000-5,000 \mathrm{AP}$ & Dyphyllobotrium sp. & Reinhard and Urban 2003 \\
\hline
\end{tabular}


vermicularis (pinworm) eggs, curiously, were only found among ancient populations who lived on the Pacific side. Molecular biology studies, however, showed interesting results, with two different pinworm lineages in the Pacific coast populations. One had the same sequences of North American lineages, but the other showed divergent nucleotides in some sequences (Iñiguez et al. 2003). According to the authors, this may be interpreted as the consequence of different origins. While one was introduced by human pre-historic migrations that crossed the Bering Land Bridge more than 20,000 years ago, the other lineage suggests an introduction by another route, in this case supporting transpacific contacts of Asian people in pre-Columbian times (Araújo, Reinhard and Ferreira 2008; Iñiguez et al. 2006).

Regarding intestinal protozoan infection, South American paleoparasitology data is not as representative, although the two most prevalent protozoan parasites found in coprolites and sediments were Entamoeba histolytica and Giardia intestinalis (Gonçalves, Araújo et al. 2002; Gonçalves, da Silva et al. 2004). Antigens of Giardia sp., Cryptosporidium sp., Cyclospora sp., and Helicobacter pilori, were identified in Andean mummies dated up to 3,000 years by fluorescent microscopy (Allison et al. 1999; Ortega and Bonavia 2003).

As evidenced by paleoparasitology finds, common human intestinal parasites were infecting South American pre-Columbian populations. Although data are still missing for many South American countries, an interesting paleoparasitological picture has been traced from Argentinean, Bolivian, Brazilian, Chilean, and Peruvian archaeological material (Ferreira et al. 2008). When these findings are compared with North American paleoparasitology, a similar picture appears and human strategies to confront different environments can be seen between the continents (Reinhard 1992).

Many of these parasites originated in Old World human populations (Araújo and Ferreira 1995). They came out of Africa with the peopling of Europe. From there, they spread through the world where climate conditions allowed transmission (Araújo, Reinhard and Ferreira 2008). However, humans acquired other parasites from animals whenever humans invaded new habitats, adopted new habits, or created new technologies amplifying their range of influence on the environment.

Humans adopted food habits according to the occupied region. This is evidenced by coprolite paleoparasitological analysis. Diphyllobothrium pacificum was a common intestinal infection in the past as it is today in the Pacific coast. The consumption of raw fish is a common habit in many countries and different cultures all over the world. Baer et al. (1967) reported the presence of D. pacificum in modern Peruvian coast population, later D. pacificum infection was confirmed in Peruvian and Chilean pre-Columbian coprolites (Araújo et al. 1983; Ferreira et al. 1984; Patrucco et al. 1983; Reinhard and Urban 2003). Diphyllobothrium pacificum human transmission is due to the consumption of raw fish containing parasites.

Echinostoma sp. eggs were found in a Brazilian mummy (Sianto et al. 2005). As this parasite was not recorded in modern South American population, the finding was carefully investigated before publishing this information. It is interesting to note that this case of Echinostoma human infection in pre-historic South America was associated with a case of Chagas disease, with intestinal lesions characterized by megacolon (Fernandes et al. 2008). In this case two important points should be emphasized: firstly, the description of Chagas disease lesions in a mummy outside the Andean region, confirmed by molecular paleoparasitology studies (Fernandes et al. 2008); secondly, an infection by Echinostoma in South American human population not yet described (Sianto et al. 2005). These findings point to the need of further detailed studies at this archaeological site.

\section{Animal Parasites in Humans}

The presence of animal parasites in human coprolites shows the use of different food resources. However, these habits may still be maintained today by traditional groups. For example, Coimbra Jr. and Mello (1981) found Capillaria eggs in modern Amazonian Indian group, and Fugassa, Bayer and Sardella (2008) identified Capillaria eggs in animal coprolites in Patagonia, which may point to a potential source of infection for humans in this region. Capillaria species rarely infect humans, but eggs can pass with feces when humans eat an infected host. Thus, the eggs can be found in human feces, but disappear after a few days.

Fugassa et al. (2006) presented an overview of human and animal intestinal helminths and protozoa found in archaeological material excavated in Patagonia. These findings illustrate the diversity 
of parasites that can be found in archaeological remains, in close contact with humans beginning 10,000 years ago. Therefore, paleoparasitology is a powerful tool to investigate the variety of food sources used by humans at different times by studying organic remains preserved in archaeological sites.

\section{Ectoparasites}

South American mummies provided positive results for ectoparasites. In the fur of mummified guinea pigs (Cavia aperea f. porcellus), numerous well-preserved ectoparasites (lice, fleas, mites) could be recovered (Dittmar 2002; Dittmar et al. 2003). Moreover, paleoparasitological examination of Amerindian clothes provided parasite finds, such as ectoparasites (Fugassa et al. 2007). Molecular biology studies were also performed (Dittmar et al. 2003; Raoult et al. 2008), as well as paleoepidemiological and quantitative attempts to evaluate head lice infection (Reinhard and Buikstra 2003). Head lice were found still attached to hair fragments of a skeleton dated to 10,000 years in northeastern Brazilian (Araújo et al. 2000). Crablouse was also found infecting Peruvian mummies (Rick et al. 2002). Rivera et al. (2008) reviewed the findings of head lice in
South American mummies recording new finds of Anthropophthirus capitis (a new genus proposed by Retana-Salazar and Ramirez-Morales 2006 to substitute Pediculus humanus capitis) in mummies of the Chinchorro tradition dated to 4,000 years. This new species proposal is very controversial, but it was proposed due to genetic similitudes found between Pediculus humanus (human body lice) and the Parapediculus (ectoparasite of South American monkeys).

To conclude, South American paleoparasitologists, together with North American colleagues, are building an evolving picture of parasite infections dated from the peopling of the Americas (Araújo, Reinhard and Ferreira 2008; Araújo, Reinhard et al. 2008). Paleoparasitological data, through the use of microscopic, immunology and molecular techniques, is an efficient way to provide information about human behavior in the past, contributing to understanding the origin and evolution of infectious diseases and their impact on prehistoric populations.

Acknowledgements: Supported by the Brazilain agencies CNPq, CAPES, and FAPERJ. We also want to thanks the Convenio Desempeño UTAMINEDUC for their support and the manuscript editors, and outside reviewers for their comments and suggestions.

\section{References Cited}

Allison, M.J., T. Bergman, and E. Gerszten 1999 Further studies on fecal parasites in antiquity. American Journal of Clinical Pathology 112(5):605-609.

Araújo, A., and L.F. Ferreira

1995 Oxiuriase e migrações pré-históricas. Historia, Ciencias, Saude - Manguinhos 2(1):99-109.

Araújo, A., L.F. Ferreira, and U. Confalonieri

1981 A contribution to the study of helminth findings in archaeological material in Brazil. Revista Brasileira de Biología 41:873-881.

Araújo, A., L.F. Ferreira, U.E. Confalonieri, L. Nuñez, and F.O. Cruz

1983 Eggs of Diphyllobothrium pacificum in precolumbian human coprolites. Paleopathology Newsletter 41:11-13.

Araújo, A., L.F. Ferreira, N. Guidon, N. Maues Da Serra Freire, K.J. Reinhard, and K. Dittmar

2000 Ten thousand years of head lice infection. Parasitology Today 16(7):269.

Araújo, A., A.M. Jansen, F. Bouchet, K. Reinhard, and L.F. Ferreira

2003 Parasitism, the diversity of life, and paleoparasitology. Memórias do Instituto Oswaldo Cruz 98:5-11.
Araújo, A., K. Reinhard, O.M. Bastos, L.C. Costa, C. Pirmez, A. Iñiguez, A.C. Vicente, C.M. Morel, and L.F. Ferreira 1998 Paleoparasitology: perspectives with new techniques. Revista do Instituto de Medicina Tropical de Sao Paulo 40(6):371-376.

Araújo, A., K. Reinhard, and L.F. Ferreira

2008 Parasite findings in archaeological remains: diagnosis and interpretation. Quaternary International 174:1-4. 180:17-21.

Araújo, A., K.J. Reinhard, L.F. Ferreira, and S.L. Gardner 2008 Parasites as probes for prehistoric human migrations? Trends in Parasitology 24:112-115.

Arriaza, B., K. Reinhard, A. Araújo, N. Orellana, and V. Standen

2010 Possible influence of the ENSO phenomenon on the pathoecology of diphyllobothriasis and anisakiasis in ancient Chinchorro populations. Memórias do Instituto Oswaldo Cruz 105(1):66-72.

Aufderheide A.C., W. Salo, M. Madden, J. Streitz, J. Buikstra, F. Guhl, B. Arriaza, C. Renier, L.E. Wittmers Jr., G. Fornaciari, and M. Allison

2004 A 9,000-year record of Chagas' disease. Proceedings of the National Academy of Sciences 101(7):2034-2039. 
Baer, J.G., H. Miranda, W. Fernandez, and J. Medina 1967 Human diphyllobothriasis in Peru. Zeitschrift für Parasitenkunde 28(3):277-289.

Bouchet F, N. Guidon, K. Dittmar, S. Harter, L.F. Ferreira, S.M. Chaves, K. Reinhard, and A. Araújo

2003 Parasite remains in archaeological sites. Memorias do Instituto Oswaldo Cruz 98(1):47-52.

Callen, O., and T.W.M. Cameron

1960 A prehistoric diet as revealed in coprolites. The New Scientist 8:35-40.

Chagnon, N.A.

1983 Yanomamo: The Fierce People. CBS College Publishing, New York, NY.

Chame, M.

2003 Terrestrial mammal feces: A morphometric summary and description. Memórias do Instituto Oswaldo Cruz 98(Suppl. I):71-94.

Cockburn, A.

1967 Infectious Diseases: Their Evolution and Eradication. Charles C. Thomas, Springfield.

1971 Infectious diseases in ancient populations. Current Anthropology 12:45-62.

Coimbra Jr., C.E.A., and D.A. Mello

1981 Enteroparasitas e Capillaria sp. entre o grupo Suruí, Parque Indígena Aripuanã, Rondônia. Memórias de Instituto Oswaldo Cruz 76:299-302.

Confalonieri, U.

1988 Paleoepidemiologia de Trichuris trichiura na América. In Paleoparasitologia no Brasil, edited by L.F. Ferreira, A. Araújo, and U. Confalonieri, pp. 120-137. Editora PEC/ ENSP, Rio de Janeiro.

Dittmar, K.

2000 Evaluation of ectoparasites on the Guinea pig mummies of El Yaral and Moquegua Valley, in Southern Peru. Chungara Revista de Antropología Chilena 32:123-125. 2002 Arthropod and helminth parasites of the wild guinea pig, Cavia aperea, from the Andes and the Cordillera in Peru, South America. Journal of Parasitology 88: 409-411.

2009 Old parasites for a New World: The future of paleoparasitological research. A review. Journal of Parasitology 95:365-371.

Dittmar, K., U. Mamat, M. Whiting, T. Goldmann, K. Reinhard, and $\mathrm{S}$. Guillen

2003 Techniques of DNA-studies on prehispanic ectoparasites (Pulex sp., Pulicidae, Siphonaptera) from animal mummies of the Chiribaya culture, Southern Peru. Memórias do Instituto Oswaldo Cruz 98:53-58.

Dittmar, K., S.M. de Souza, and A. Araújo

2006 Challenges of phylogenetic analyses of aDNA sequences. Memorias do Instituto Oswaldo Cruz 101:9-13.

Fernandes, A., A.M. Iñiguez, V.S. Lima, S.M. de Souza, L.F. Ferreira, A.C. Vicente, and A.M. Jansen

2008 Pre-Columbian chagas disease in Brazil: Trypanosoma cruzi $\mathrm{I}$ in the archaeological remains of a human in Peruaçu Valley, Minas Gerais, Brazil. Memórias do Instituto Oswaldo Cruz 103:514-516.

Ferreira L.F., A. Araújo, and U. Confalonieri 1988 Paleoparasitologia no Brasil. Ed. PEC/ENSP-FIOCRUZ, Rio de Janeiro.
Ferreira, L.F., A.J.G. Araújo, and U.E.C. Confalonieri 1982 The finding of helminth eggs in a Brazilian mummy. Tropical Medicine \& Hygiene 77(1):65-67.

Ferreira, L.F., A.J. de Araújo, U.E. Confalonieri, and L. Nuñez

1984 The finding of eggs of Diphyllobothrium in human coprolites (4,100-1,950 B.C.) from Northern Chile. Memórias do Instituto Oswaldo Cruz 79:175-180.

Ferreira, L.F., C. Britto, M.A. Cardoso, O. Fernandes, K. Reinhard, and A. Araújo

2000 Paleoparasitology of Chagas disease revaled by infected tissues from Chilean mummies. Acta Tropica 75:79-84.

Ferreira, L.F., K. J. Reinhard, and A. Araújo

2008 Paleoparasitologia. Ed. Fiocruz, Rio de Janeiro, Brasil.

Fornaciari, G., M. Castagna, P. Viacava, A. Togneti, G. Bevilaqua, and E.L. Segura

1992 Chagas' disease in Peruvian Inca mummy. Lancet 339:128-129.

Fugassa, M.H.

2006 Enteroparasitosis en Poblaciones CazadorasRecolectoras de Patagonia Austral. Tesis Doctoral. Universidad Nacional de Mar del Plata, Buenos Aires.

2007 Camélidos, parásitos y ocupaciones humanas: registros paleoparasitológicos en Cerro Casa de Piedra 7 (Parque Nacional Perito Moreno, Santa Cruz, Argentina). Intersecciones en Antropología 8:265-269.

2008 Aportes paleoparasitológicos para el sitio arqueológico CCP7, P. N. Perito Moreno, Santa Cruz. Cuadernos del Instituto Nacional de Antropología y Pensamiento Latinoamericano 21:263-265.

Fugassa, M.H., A. Araújo, and R.A. Guichón

2006 Quantitative paleoparasitology applied to archaeological sediments. Memórias do Instituto Oswaldo Cruz 101:29-33.

Fugassa, M.H., M.S. Bayer, and N.H. Sardella

2008 Examen paleoparasitológico de coprolitos de felinos en Patagonia (Holoceno Medio). Manuscript in possession of the authors.

Fugassa M. H., A. Cicchino, N. H. Sardella, R. A. Guichón, G. M. Denegri, and A. Araújo

2007 Nuevas fuentes de evidencia para la paleoparasitología y la antropología biológica en Patagonia. Revista de la Asociación de Antropología Biológica 9:51-57.

Fugassa, M.H., A., Cicchino, N. H. Sardella, R.A. Guichón, G.M. Denegri, and A. Araújo

2008 Nuevas fuentes de evidencia para la paleoparasitología y la antropología biológica en Patagonia. Revista Argentina de Antropología Biológica 9:51-57.

Fugassa, M.H., G.M. Denegri, N.H. Sardella, A. Araújo, R.A. Guichón, P.A. Martinez, M.T. Civalero, and C. Aschero

2006 Paleoparasitological records in canid coprolite from Patagonia, Argentina. Journal of Parasitology 92:11101113.

Fugassa, M.H., N.H. Sardella, R.A. Guichón, G.M. Denegri, and A. Araújo

2008 Paleoparasitological analysis applied to museum-curated sacra from meridional Patagonian collections. Journal of Archaeological Science 35:1408-1411. 
Fugassa, M.H., V. Taglioretti, M.L.C. Gonçalves, A. Araújo, N.H. Sardella, and G.M. Denegri

2008 Capillaria spp. findings in Patagonian archaeological sites: Statistical analysis of morphometric data. Memórias do Instituto Oswaldo Cruz 103:104-105.

Gárate, I., B. Suyo, M. Delgado, H. Solís, and P. Castellanos 2005 Hallazgo de nematode y huevos de Ascaris sp. en coprolitos de la momia "Shamana Alada", Cerrilos, Ica, Peru. Boletín Chileno de Parasitología y de Parasitología al Día 60 (T2):325.

Gonçalves, M.L., A. Araújo, R. Duarte, J.P. da Silva, K. Reinhard, F. Bouchet, and L.F. Ferreira

2002 Detection of Giardia duodenalis antigen in coprolites using a commercially available enzyme-linked immunosorbent assay. Transactions of the Royal Society of Tropical Medicine and Hygiene 96:640-643.

Gonçalves, M.L., A. Araújo, and L.F. Ferreira

2003 Human intestinal parasites in the past: New findings and a review. Memórias do Instituto Oswaldo Cruz 98: 103-118.

Gonçalves, M.L., V.L. da Silva, C.M. de Andrade, K. Reinhard, G.C. da Rocha, M. Le Bailly, F. Bouchet, L.F. Ferreira, and A. Araújo

2004 Amoebiasis distribution in the past: First steps using an immunoassay technique. Transactions of the Royal Society of Tropical Medicine and Hygiene 98:88-91.

Guhl, F., C. Jaramillo, G.A. Vallejo, F. Cárdenas-Arroyo, and A. Aufderheide

2000 Chagas disease and human migration. Memórias do Instituto Oswaldo Cruz 95:553-555.

Guhl, F., C. Jaramillo, G.A. Vallejo, R. Yockteng, F. CárdenasArroyo, G. Fornaciari, B. Arriaza, and A.C. Aufderheide 1999 Isolation of Trypanosoma cruzi DNA in 4,000-year-old mummified human tissue from Northern Chile. American Journal of Physical Anthropology 108:401-407.

Guichón, R.A., J.A. Suby, R. Casali, and M.H. Fugassa

2006 Health at the time of Native-European contact in Southern Patagonia: First steps, results, and prospects. Memórias do Instituto Oswaldo Cruz 101:97-105.

Harter, S., M. Le Bailly, F. Janot, and F. Bouchet

2003 First paleoparasitological study of an embalming rejects jar found in Saqqara, Egypt. Memórias do Instituto Oswaldo Cruz 98:119-121.

Harter-Lailheugue S., and F. Bouchet

2006 Etude paléoparasitologique d'éléments atypiques de la Basse et Haute Vallée du Nil. Bulletin de la Société de Pathologie Exotique 99:53-57.

Heck, J.

2004 Krankheit und körperdeformation in darstellungen auf Moche-Tongefäßen analyse und synopse aus ärztlicher Sicht. Baessler-Archiv 52:105-124.

Heckenberger, M.J., J.C. Russell, C. Fausto, J.R. Toney, M.J. Schmidt, E. Pereira, B. Franchetto, and A. Kuikuro 2008 Pre-Columbian urbanism, anthropogenic landscapes, and the future of the Amazon. Science 321:1214-1217.

Iñiguez, A.M., K.J. Reinhard, A. Araújo, L.F. Ferreira, and A.C. Vicente

2003 Enterobius vermicularis: ancient DNA from North and South American human coprolites. Memórias do Instituto Oswaldo Cruz 98:67-69.
Iñiguez, A.M., K. Reinhard, M.L. Carvalho Gonçalves, L.F. Ferreira, A. Araújo, and A.C. Paulo Vicente

2006 SL1 RNA gene recovery from Enterobius vermicularis ancient DNA in pre-Columbian human coprolites. Internatinal Journal for Parasitology 36:1419-1425.

Jones, A.

1982 Recent finds of intestinal parasites ova at York, England. Papers on Paleopathology. $4^{\text {th }}$ European Members Meeting, Middelburg, Antwerpen, p. 7.

Leles, D., A. Araújo, L.F. Ferreira, A.C. Vicente, and A.M. Iñiguez

2008 Molecular paleoparasitological diagnosis of Ascaris sp. from coprolites: new scenery of ascariasis in pre-Colombian South America times. Memórias do Instituto Oswaldo Cruz 103:106-108.

Le Bailly, M., M.L. Gonçalves, S. Harter-Lailheugue, F. Prodéo, A. Araújo, and F. Bouchet

2008 New finding of Giardia intestinalis (Eukaryote, Metamonad) in Old World archaeological site using immunofluorescence and enzyme-linked immunosorbent assays. Memórias do Instituto Oswaldo Cruz 103:298-300.

Lima, V., A. Iñiguez, K. Otsuki, LF, Ferreira, A. Araújo, A. Vicente, and A. Jansen

2008 Chagas disease by Trypanosoma cruzi lineage I in hunter-gatherer ancient population in Brazil. Emerging Infectious Diseases 14:1001-1002.

Loreille, O., and F. Bouchet

2003 Evolution of ascariasis in humans and pigs: a multidisciplinary approach. Memórias do Instituto Oswaldo Cruz 98:39-46.

Loreille, O., E. Roumat, O. Verneau, F. Bouchet, and C. Hänni 2001 Ancient DNA from Ascaris: extraction amplification and sequences from eggs collected in coprolites. International Journal of Parasitology 31:1101-1106.

Lutz, A.

1919 O Schistosomum mansoni e a schistosomatose, segundo observações feitas no Brasil. Memórias do Instituto Oswaldo Cruz 11:121-150.

Martinson, E., K.J. Reinhard, J.E. Buikstra, and K. Dittmar 2003 Pathoecology of Chiribaya parasitism. Memórias do Instituto Oswaldo Cruz 98:195-205.

Medeiros, R.P.

2002 Povos indígenas do sertão nordestino no período colonial: descobrimento, alianças, resistência e encobrimento. FUMDHAmentos 2:7-52.

Montenegro, A., A. Araújo, M. Eby, L.F. Ferreira, R. Hetherington, and A. Weaver

2006 Parasites, paleoclimate and the peopling of the Americas: using the hookworm to time the Clovis migration. Current Anthropology 47:193-198.

Ortega, Y.R., and D. Bonavia

2003 Cryptosporidium, Giardia, and Cyclospora in ancient Peruvians. Journal of Parasitology 89:635-636.

Patrucco, R., R. Tello, and D. Bonavia 1983 Parasitological studies of coprolites of pre-hispanic Peruvian populations. Current Anthropology 24:393-394.

Pizzi, T., and H. Schenone

1954 Hallazgo de huevos de Trichuris trichiura en el contenido intestinal de un cuerpo arqueológico arcaico Inca. Boletín Chileno de Parasitología 9:73-75. 
Pruvost, M., R. Schwarz, V.B. Correia, S. Champlot, S. Braguier, N. Morel, Y. Fernandez-Jalvo, T. Grange, and E.M. Geigl 2007 Freshly excavated fossil bones are best for amplification of ancient DNA. Proceedings of the National Academy of Sciences 104:739-744.

Raoult, D., and M. Drancourt

2008 Paleomicrobiology: Past Human Infections. SpringerVerlag, Berlin Heidelberg.

Raoult, D., D.L. Reed, K. Dittmar, J.J. Kirchman, J.M. Rolain, S. Guillen, and J.E. Light

2008 Molecular identification of lice from pre-Columbian mummies. Journal of Infectious Diseases 197:535-543.

Reinhard, K.J.

1988 Cultural ecology of prehistoric parasitism on the Colorado Plateau as evidenced by coprology. American Journal of Physical Anthropology 77:355-366.

1990 Archaeoparasitology in North America. American Journal of Physical Anthropology 82:145-163.

1992 Parasitology as an interpretive tool in archaeology. American Antiquity 57:231-245.

2008 Parasite pathoecology of chacoan great houses: the healthiest and wormiest ancestral puebloans. In Chaco's Northern Prodigies Salmon, Aztec, and the Ascendancy of the Middle San Juan Region after AD 1100, edited by P.F. Reed, pp. 86-95. University of Utah Press, Salt Lake City.

Reinhard, K., A. Araújo, L.F. Ferreira, and C.E. Coimbra 2001 American hookworm antiquity. Medical Anthropology 20:96-101.

Reinhard, K.J., and V.M. Bryant 2008 Pathoecology and the future of coprolite studies in bioarchaeology. In Reanalysis and Reinterpretation in Southwestern Bioarchaeology, edited by A.W.M. Stodder, pp. 205-224. Arizona State University Press, Tempe.

Reinhard, K., and J. Buikstra

2003 Louse infestation of the Chiribaya Culture, Southern Peru: variation in prevalence by age and sex. Memórias do Instituto Oswaldo Cruz, 98:173-179.

Reinhard, K., and O. Urban

2003 Diagnosing ancient diphyllobothriasis from Chinchorro mummies. Memórias do Instituto Oswaldo Cruz 98:191-193.
Retana-Salazar, A.P., and R. Ramirez-Morales

2006 Establecimiento de un nuevo género de piojos (Phthiraptera: Pediculidae) asociado al hombre (Primates: Hominidae). Brenesia 65:61-70.

Rick, F.M., G.C. Rocha, K. Dittmar, C.E. Coimbra Jr, K. Reinhard, F. Bouchet, L.F. Ferreira, and A. Araújo

2002 Crab louse infestation in pre-Columbian America. Journal of Parasitology 88:1266-1267.

Rivera, M.A, K.Y. Mumcuoglu, R.T. Matheny, and D.G. Matheny

2008 Huevecillos de Anthropophthirus capitis en momias de la tradición Chinchorro, Camarones 15-D, Norte de Chile. Chungara Revista de Antropología Chilena 40:31-39.

Rothhammer, F., M.J. Allison, L. Núñez, V. Standen, and B. Arriaza

1985 Chagas' disease in pre-Columbian South America. American Journal of Physical Anthropology 68:495-498.

Salo, W., A. Aufderheide, J. Buikstra, and T. Holcomb 1994 Identification of Mycobacterium tuberculosis DNA in a pre-Columbian Peruvian mummy. Proceedings of the National Academy of Sciences 91:2091-2094.

Santoro, C., S.D. Vinton, and K. Reinhard

2003 Inca expansion and parasitism in the Lluta Valley: preliminary data. Memórias do Instituto do Oswaldo Cruz 98:161-163.

Sianto, L., K.J. Reinhard, M. Chame, S. Chaves, S. Mendonça, M.L. Gonçalves, A. Fernandes, L.F. Ferreira, and A. Araújo

2005 The finding of Echinostoma (Trematoda: Digenea) and hookworm eggs in coprolites collected from a Brazilian mummified body dated 600-1,200 years before present. Journal of Parasitology 91:972-975.

Solis, R.S., J. Haas, and W. Creamer

2001 Dating Caral, a preceramic site in the Supe Valley on the central coast of Peru. Science 292:723-726.

Williams A., C.M. Santoro, M.A. Smith, and C. Latorre 2008 The impact of ENSO in the Atacama Desert and Australian arid zone: exploratory time-series analysis of archaeological records. Chungara Revista de Antropología Chilena 40:245-259. 